\title{
Electronic Procurement Negotiation Process From An Actor Network Theory Perspective
}

\author{
Mohamed Fathi alaweti ${ }^{1}$, Nurdiana Azizan $^{2}$, Qaise Faryadi ${ }^{3}$ \\ Faculty of Science and Technology, Universiti Sains Islam Malaysia \\ Mralakrami@gmail.com ${ }^{1}$, nurdiana@usim.edu.my ${ }^{2}$, gaise@usim.edu.my ${ }^{3}$
}

\begin{abstract}
The paper presents a case study of the use of existing electronic procurement (E-procurement) negotiations processes. It focuses on reviewing the negotiations processes that the system introduces. It, then, applies the Actor Network Theory's (ANT) notions of associations and power in order to illustrate that the negotiations processes introduce a new power circuit effect. In so doing, it aims to provide insight into the performing strong relation in social and technical of both human and non-human actors network that the newly introduced system negotiations processes constructs. A qualitative data method applied in this study, then it suggests that the $\mathrm{E}$ procurement system should negotiation processes would affect the social and organisational architecture of the organisation and its established performing power networks.
\end{abstract}

Keywords- Actor Network Theory (ANT), E-Procurement, negotiations processes, qualitative method.

\section{Council for Innovative Research}

Peer Review Research Publishing System

Journal: International Journal of Management \& Information Technology

Vol. 10, No. 1

editor@cirworld.com

www.cirworld.com, member.cirworld.com 


\section{INTRODUCTION}

E-Procurement, refers to the use by government agencies of information technologies (such as Wide Area Networks, the Internet, and mobile computing) that have the ability to transform relations with citizens, businesses, and other arms of E-government" Avgerou (2006). Selcen et al. (2009) are noted that e-government initiatives are expected to result in better delivery of E-Procurement system services to citizens, improved interactions with business and industry, citizen empowerment through access to information, and more efficient government management. In addition, Akman et al. (2005) expected side benefits involve less corruption, increased transparency, greater convenience, revenue growth, and cost reductions.

E-procurement research has been typically occupied by studying B2B and trying to see the new market relationships introduced by such a system (Lucking-Reiley and Spulber, 2000). It focuses more on the transaction costs and how to achieve the optimum economic benefits (Wigand 1997) as mention (Garicano and Kaplan 2000). The social and organisational implications of E-procurement systems have not yet received much attention. Recognising the gap, authors call for the need to explore and understand "the thorny and difficult social and organisational issues" involved in implementing and using such systems (Chong and Liu, 2000).

The Actor Network Theory is appropriate for use in this study, because it identifies and acknowledges the key human actors and non-human actors within an organisation, and the effect that such actors may have on the potential social issues that might occur. ANT is used to investigate issues in the negotiation process that incorporate human actors such as buyers and suppliers, to investigate how the interaction between these actors can affect the negotiation process (Noraizah and Konrad 2012).

Furthermore, a qualitative method will apply to identifying and understanding the social issues that influence the negotiation process chain between partners. As such, it is hoped that greater success output with E-procurement will be achieved. The significance of this research is to provide knowledge to practitioners on the importance of the negotiation process between partners in an E-procurement network. By identifying and understanding the factors that influence the negotiation process (Croom and Jones 2007).

\section{BACKGROUND LITERATURE}

2.1 E-procurement systems: IT vendors have developed a wide range of web-enabled solutions to support organizational E-procurement process. These systems (which are commonly known as e-procurement systems) automate and streamline the key activities involved in a procurement process. E-procurement systems generally use the Internet (as a communicating medium), web protocols to exchange procurement related data between a buying organization and its suppliers, e-catalogues for products, and a powerful search engine to browse the catalogue. In a broad sense, E-procurement systems can be regarded as the application of e-commerce technologies to an organization's purchasing activities (Garrido-Samaniego et al. 2010).

2.2 E-procurement systems benefits: The benefits of E-procurement systems among organizations are widely recognized (Ronchi et al. 2010). According to Wen and Wei (2007), these benefits can be ideally classified into two broad categories: operational and strategic. Operational benefits are generally concerned with efficiency improvement, transaction cost reduction and increased control among others, whereas strategic benefits focus more on buyer and supplier relationships, image building, and competitive position enhancement. A summary of how a typical Eprocurement system, upon its successful implementation, can provide benefits to organizations is given in Table 1 and is explained below.

2.3 Actor-Network Theory (ANT): or known as the 'sociology of translations', focuses on the hybrid human/nonhuman products of the interactions between all the relevant entities within the system (Latour, 2005; Callon, 1991; Law, 1992). It is attentive to the ways human and material entities interact to produce novel forms, which then impact on other things within the system, producing larger units of influence, all of which together determine how the system works. This approach seeks explanations for the system's stability or instability, successes or failures, within this broad 'co-constructivist' picture.

2.4 ANT as an Analytical Framework: A key principle of ANT, which it shares with some related approaches to analyzing social-technical systems (STSs), is to reserve judgment, at the outset, as to whether the influences in a system are coming primarily from human or non-human elements. Both these are seen as mutually formative of each other. The point is that whilst technology is a thoroughly social construction, society is a technological construction as well (Kirsch, 1995). The strength of STSs is the attention they pay to the formative influence of both human and nonhuman 'actors' on the performance of a E-procurement negotiation process system. They can also reveal how nonhuman things can determine power relations, either by design or default Sin et al. (2006).

\section{RESEARCH METHODOLOGY}

This research obtained the qualitative research in information systems (Kaplan \& Maxwell, 1994). It adopts an interpretive case study approach (Orlikowski and Baroudi, 1991). The case presented here is part of a larger research project that followed the implementation of an E-procurement system, within which E-procurement was implemented.

The data collection of the original research project took place between February 2012 and February 2014. The main method of data collection, throughout the study, has been participant observation of most of the meetings, and $E$ procurement systems prior to its going live. This is in addition to documents and project intranet review. The 
researcher also had free access to three casa study documents including "the highly restricted" internal ones. Regarding E-procurement system, To specifically explore two departments' experience with the E-procurement system, nine interviews were conducted with all case studies E-procurement department's managers, all employees involved in the E-procurement process including requisitioners and approvers, a member of the core project communication team, three from the corporate service center (a manager and two senior employees) responsible for processing purchasing orders for these departments, two consultants, and three project managers. The organisations did not permit tape recording any of the interviews or project meetings, hence the researcher had to take notes and write down observations during the interview and extend them and add more observations directly after each interview and meeting.

As the detail of the three individual cases summary of economic agents indicates (Table 3.1), there have been reflections of how performance is being measured on a short-term and long-term basis. To arrive at these findings, each respondent would first be interviewed by explaining the purposes and importance of the research. Once a respondent has agreed to participate, the interview would be made to the respondent. Table 3.1 below summarizes details of the five cases.

Table 3.1: key personal Interviewees

\begin{tabular}{|l|l|l|l|l|l|}
\hline & N & Male & Female & ICT & economic agents/ Departments \\
\hline 1 & 10 & 4 & 6 & EP & Education \\
\hline 2 & 8 & 6 & 2 & EP & Financial institutions \\
\hline 3 & 5 & 3 & 2 & EP & University \\
\hline
\end{tabular}

\section{RESEARCH MODEL}

The research model of this study is derived from a comprehensive study of organizational behaviour and the influence of E-procurement on modern negotiation process. The research model shows the importance of E-procurement on procurement environment and the impact and power of negotiation process on decision-making process, which is associated with two factors (human: Culture, Trust, Corporate social responsibility and Price) and (nonhuman: Performance of suppliers, Suppliers' offer, Awareness in choosing suppliers and Communication issues ) These factors are affected by negotiation process from ANT theory perspective, whereas The position of machines in ANT is unique since it is recognized that technologies do not evolve under the impetus of scientific logic as technological determinism suggests machines are not possessed of an inherent momentum that allows them, to pass through a neutral social medium (Stanforth 2006). In effect, "our technologies mirror our societies" as they are continuously shaped and reshaped by the interplay of a range of heterogeneous forces within the networks" (Bijker and Law 1992) (Stanforth 2006).

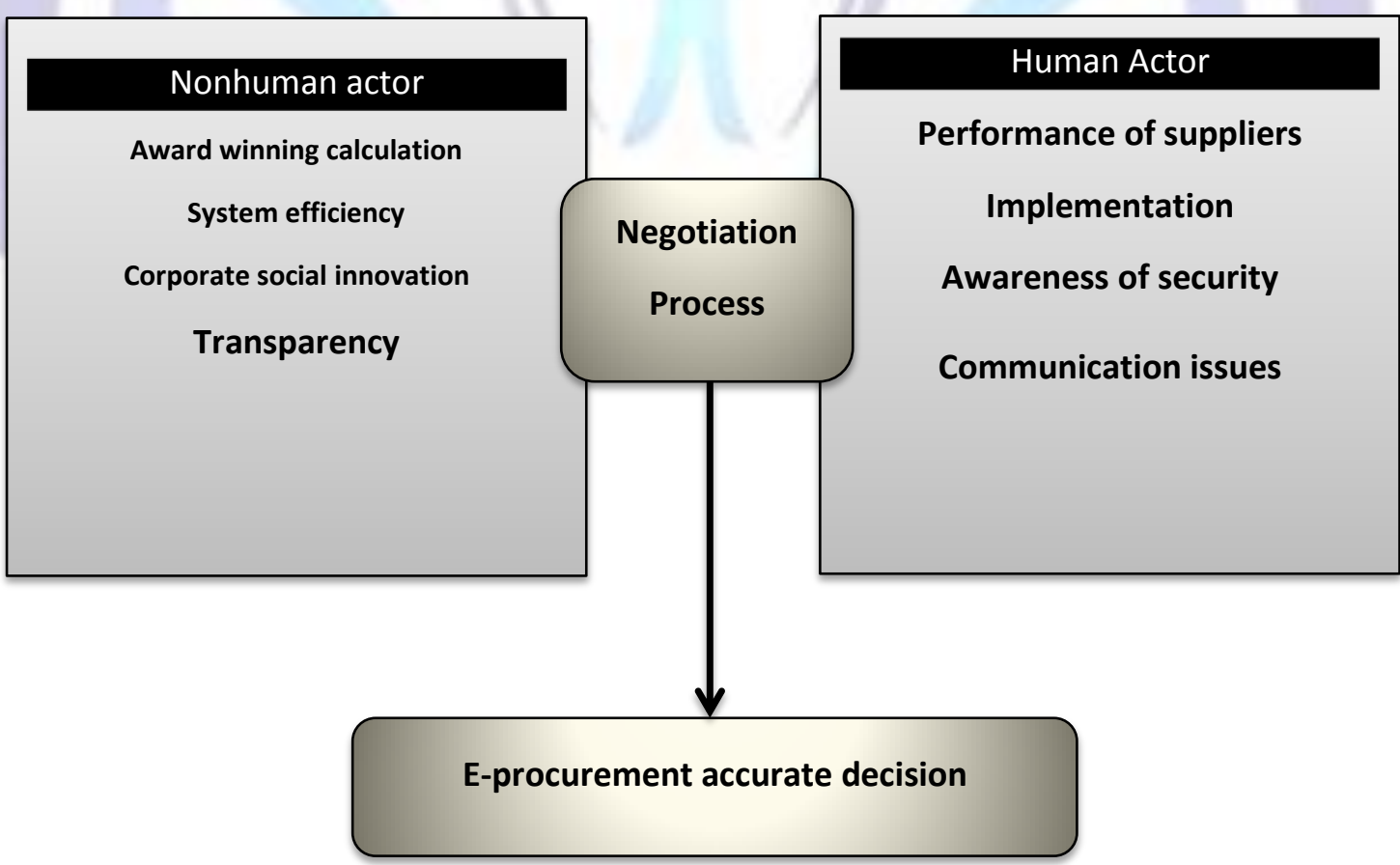

Fig 4.1: research model 


\section{FINDINGS AND ANALYSIS}

This section provides a cross-case analysis and discussion of the social issues and other issues that influence negotiation from both the human and nonhuman perspectives. The cross-case analysis was conducted in view of the cases discussed in the private sector by comparing the social issues and other issues identified from each case, the similarities and differences between the social issues and other issues that influence negotiation in e-procurement are discovered.

\subsection{Main Advantage and Disadvantage of Using E-procurement}

The interview has been to extract respondent's ideas of E-procurement performances and performances efficiencies in suppliers' and buyer's organizations respectively. They have been urged to mention the main advantages and disadvantages of using E-procurement for suppliers in their SMPPs firms and for buyers in their organizations.

As noted above, understanding about E-procurement has been their perception of what E-procuring goods and items of procurement practices in the buyers' organizations during the qualitative approaches of the study. However, knowledge of their understanding of E-procurement has been taken as an initial approach of qualitative investigation of the study. As a result, based on the deliberation with these suppliers and buyers, the following information of advantages and disadvantages of electronic purchase that can explain ANT has been revealed. The advantage of electronic purchase through the internet and other information and networking system from suppliers' organization perspective are as follows:

\begin{tabular}{|c|c|c|}
\hline $\begin{array}{l}\text { E-procurement supplier's } \\
\text { organization }\end{array}$ & $\begin{array}{l}\text { Tools and } \\
\text { Characteristics of ANT }\end{array}$ & $\begin{array}{l}\text { Buyers and Services } \\
\text { Providers }\end{array}$ \\
\hline $\begin{array}{l}\text { A. Advantage: } \\
+\quad \begin{array}{l}\text { Improve system } \\
\text { information across all areas } \\
\text { of purchase }\end{array} \\
+\quad \begin{array}{l}\text { Instant access to catalogues } \\
\text { and products }\end{array} \\
+\quad \begin{array}{l}\text { Improve transparency and } \\
\text { interoperability }\end{array} \\
+\quad \text { Faster procurement } \\
+\quad \text { Lower overload and multi } \\
\text { cast. } \\
+\quad \text { Payment received on time } \\
+\quad \text { Improve purchasing } \\
\text { purchase. } \\
\text { B. Disadvantage } \\
+\quad \text { Item and system error } \\
+\quad \text { Human eliminate shall } \\
\text { involve which can be more } \\
\text { transparent to the suppliers. }\end{array}$ & $\begin{array}{l}\text { Electronic } \\
\text { marketplaces (many- } \\
\text { to-many e- } \\
\text { procurement) }\end{array}$ & 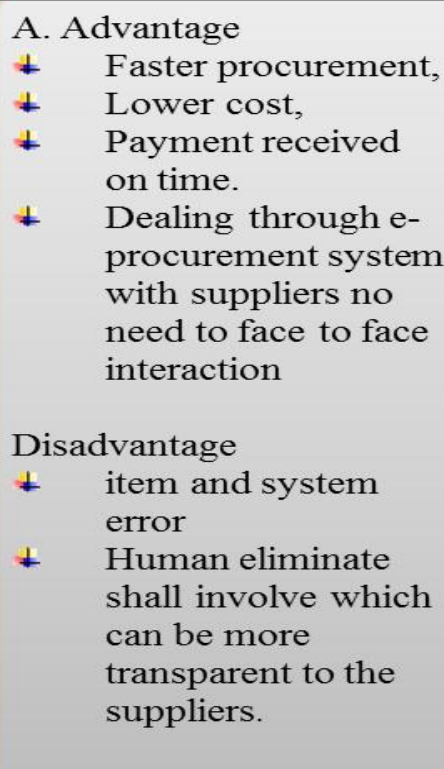 \\
\hline
\end{tabular}

Figure 5.1: advantage and disadvantage of E-procurement system performance that influences social issues between actors from buyers and suppliers perspectives.

\subsection{Implementation of the E-Procurement Strategy and Staffs Professionalisms}

Perceptions of E-procurement performance efficiency from buyers' perspectives are affected by how the implementation of the E-procurement and how the suppliers act to enforce commodity transaction process. As mentioned above, suppliers (sellers) take many steps in their commodity transaction process to do businesses with their customers be it a repeat customers and/or suppliers know the buyers and a new customers and/or suppliers do not know the buyers. This is consistence with the implementation of the E-procurement strategy.

As such, one of the many interviews, in the interviewing processes was regarding the implementation of $E$ procurement strategy in the buyer/supplier firms and the responsible persons for implementations of E-procurement in the respective organizations. This question was based on the aims of extracting information from responsible parties who were otherwise responsible for the implementations of the E-procurement strategy in the suppliers' organizations. Thus, the interview was to understand the responsible parties for the implementation of the E-procurement strategy mainly to underpin how E-procurement strategies are formulated and implemented in an organisation as a whole. In particular, to understand whether E-procurement strategies formulations and implementations in an organization are merely organisational elements that could be accomplished by the organizations' workforces at any given time that could be by anyone in the organization or by particular personnel in the organization. 


\begin{tabular}{|c|c|c|}
\hline $\begin{array}{l}\text { E-procurement supplier's } \\
\text { organization }\end{array}$ & $\begin{array}{l}\text { Tools and Characteristics of } \\
\text { ANT }\end{array}$ & $\begin{array}{l}\text { Buyer and service } \\
\text { provider organization }\end{array}$ \\
\hline $\begin{array}{ll}+\quad \text { Director } \\
+\quad \text { General Manager } \\
+\quad \text { Technical system } \\
\text { (IT managers), and } \\
+\quad \text { Staffs who are } \\
\quad \text { Professionals }\end{array}$ & $\begin{array}{l}\text { Supplier catalogue sites } \\
\text { (sell-side e-procurement) } \\
\text { Buying/ RTP applications } \\
\text { (buy-side e-procurement) } \\
\text { Responsibility } \\
\text { Implementation } \\
\text { E-procurement Strategy } \\
\text { Organization }\end{array}$ & $\begin{array}{ll}+\quad \text { Director } \\
+\quad \text { General Manager } \\
+\quad \text { Technical system } \\
\text { (IT managers), and } \\
+\quad \text { Financial } \\
\text { department }\end{array}$ \\
\hline
\end{tabular}

Figure 5.2: responsibility, implementation and strategy of E-procurement system from buyers and suppliers perspectives

\subsection{Importance of Security in E-procurement in Service Provider and Buyers}

The importance of security of internet regarding the E-procurement practices can transcend even all interactions of suppliers and buyers, which is the functions of both the department of service provider of E-procurement practices and E-procurement practices of the buyers. Therefore, the importance of security in both the department of service provider and buyers of the E-procurement practices, the LOI is first logged in and sent to suppliers research lead for review. This review consists of running the key names (company, LOI signatory, banking) through suppliers' database to ensure that there are no issues with the LOI itself. Suppliers allow 24 hours for this review (if there are any issues, they double check to ensure they are correct in their assessment). Therefore, the importance of security in Eprocurement has transcended and thus has been deliberated with the suppliers' views as follows: Important to:

1- Protect suppliers' interest and protect information leaks,

2- Ensure the real technical and financial requirement is done professionally leading, and

3- To build the trust in the system and let it moves forward

\begin{tabular}{||l|l|l|}
\hline $\begin{array}{l}\text { E-procurement supplier's } \\
\text { organization }\end{array}$ & $\begin{array}{l}\text { Tools and Characteristics of } \\
\text { ANT }\end{array}$ & $\begin{array}{l}\text { Buyer and service } \\
\text { provider organization }\end{array}$ \\
\hline $\begin{array}{l}\text { Absolute protections of } \\
\text { suppliers' interest and } \\
\text { protect information } \\
\text { leaked } \\
\begin{array}{l}\text { To ensure the real } \\
\text { technical and financial } \\
\text { requirement is done } \\
\text { professionally leading, } \\
\text { and }\end{array}\end{array}$ & $\begin{array}{l}\text { Supplier catalogue sites } \\
\text { (sell-side e-procurement), } \\
\text { Buying/ RTP applications } \\
\text { (buy-side e-procurement) }\end{array}$ & $\begin{array}{l}\text { To protect supplier's } \\
\text { information and protect } \\
\text { information of buyers } \\
\text { bidding price and all data } \\
\text { must change to codes. }\end{array}$ \\
$\begin{array}{l}\text { To build the trust in the } \\
\text { system and let it moves } \\
\text { forward. }\end{array}$ & $\begin{array}{l}\text { E-procurement processes } \\
\text { Importance of security and }\end{array}$ & $\begin{array}{l}\text { To build the trust in the } \\
\text { system and let it moves } \\
\text { forward. }\end{array}$ \\
\hline $\begin{array}{l}\text { Similar characteristics between social issues that influences importance of security and E-procurement } \\
\text { processes in e-procurement in the SMPPs firms from buyers and suppliers perspectives }\end{array}$ \\
\hline
\end{tabular}

Figure 5.3: Actors' security concern in E-procurement in the SMPPs firms from buyers and suppliers perspectives 


\subsection{Main Issues Facing Suppliers and Buyers Organization during Working Time with the Current E- Procurement System}

From the interviews, the respondent's issues facing during their work with the current E-procurement system. If there are issues, suppliers contact the buyer's representative/source and discuss their concerns with the goal of resolving any issues prior to proceeding to this step. Issues can arise from Communication, accessibility to the person using the system with or response of timing and system or server down and so on. This is due to the seller's team must deal with the timely request as stated in the LOI with sourcing, product availability and pricing. As a result, the sixth question was about the main issues facing employees and had been deliberated. While No one from buyer and service providers' organization mentioned that there was problem, suppliers organization deliberated some of their concerns as follows:

1- Communication issues,

2- Accessibility to the person close to the use of the system,

3- Response on time crisis, and

4- System down

\begin{tabular}{|c|c|c|}
\hline $\begin{array}{l}\text { E-procurement supplier's } \\
\text { organization }\end{array}$ & $\begin{array}{l}\text { Tools and Characteristics of } \\
\text { ANT }\end{array}$ & $\begin{array}{l}\text { Buyer and service } \\
\text { provider organization }\end{array}$ \\
\hline $\begin{array}{l}\text { Main issues suppliers } \\
\text { have faced during their } \\
\text { work with the current E- } \\
\text { procurement system }\end{array}$ & $\begin{array}{l}\text { Supplier catalogue sites } \\
\text { (sell-side e-procurement) } \\
\text { Buying/ RTP applications } \\
\text { (buy-side e-procurement) } \\
\text { Communication issues, } \\
\text { Accessibility to the person } \\
\text { close to the use of the } \\
\text { system, } \\
\text { Response on time crisis, and } \\
\text { System down }\end{array}$ & $\begin{array}{l}\text { Main issues buyers have } \\
\text { faced during their work } \\
\text { with the current E- } \\
\text { procurement system }\end{array}$ \\
\hline
\end{tabular}

Figure 5.4: similar characteristics of communication issues that influences E-procurement from buyers and suppliers perspectives

However, from buyer's organization side, no one mention there was problems. The idea is that they build the system and there no issues.

Figure 5.4 shows differences and similarities characteristics of social issues that influences E-procurement practices from buyers and suppliers perspectives.

\subsection{Decision-Making and Problem Solving Processes and E-Procurement System}

The question was about decision-making and problem solving processes and the effects of decisions and solutions on E-procurement system among the suppliers' and buyers' organizations. The first interview of this question was about the main factors that affect the decision-making processes in using E-procurement system and E-procurement practices among the supplier's and buyer's organizations. The answer to this question from suppliers' perspectives has been:

1. Price,

2. Company history,

3. Experience, and

4. Documents presentation 


\begin{tabular}{|c|c|c|}
\hline $\begin{array}{l}\text { E-procurement supplier's } \\
\text { organization }\end{array}$ & $\begin{array}{l}\text { Tools and Characteristics of } \\
\text { ANT }\end{array}$ & $\begin{array}{l}\text { Buyer and service } \\
\text { provider organization }\end{array}$ \\
\hline $\begin{array}{l}\text { Price, } \\
\text { Company history, } \\
\text { Experience, } \\
\text { Documents presentation }\end{array}$ & $\begin{array}{l}\text { Electronic marketplaces } \\
\text { (many-to-many e- } \\
\text { procurement) } \\
\text { Main factors that affect the } \\
\text { decision-making using E- } \\
\text { procurement system }\end{array}$ & $\begin{array}{l}\text { Lowest price, } \\
\text { Time to accomplish the } \\
\text { process, } \\
\text { Company history } / \text { not in } \\
\text { the black list by other } \\
\text { organizations, } \\
\text { Experience, } \\
\text { Documents } \\
\text { presentation, and } \\
\text { Items quality, }\end{array}$ \\
\hline
\end{tabular}

Figure 5.5: similar characteristics of social issues that influences decision-making in E-procurement practices from buyers and suppliers perspectives

While from buyers perspectives it has been:

1. Lowest price,

2. time to accomplished the process,

3. company history/not in the black list by other organizations,

4. experience,

5. documents presentation, and

6. Items quality

\subsection{The Efficiency of E-Procurement System Process}

The interview of this question was about the major obstacles that the supplier's and buyer's organizations may have faced in procuring goods and services through an E-procurement system and E-procurement process in achieving the desired goals of their organizations during the study periods. The answers to such questions have been among other things such as:

1. System downtime,

2. Customer service operator or slow respond,

The specification for product not clearly noticed and suppliers are not apple to comparison. (Meaning that buyers item not clear some time or what they want precisely).

\begin{tabular}{|c|c|c|}
\hline $\begin{array}{l}\text { E-procurement supplier's } \\
\text { organization }\end{array}$ & $\begin{array}{l}\text { Tools and Characteristics of } \\
\text { ANT }\end{array}$ & $\begin{array}{l}\text { Buyer and service } \\
\text { provider organization }\end{array}$ \\
\hline $\begin{array}{l}\text { System downtime, } \\
\text { Customer service } \\
\text { operator or slow respond, } \\
\text { The specifications for } \\
\text { product no clear notice } \\
\text { Comparisons are not } \\
\text { applicable for } \\
\text { (Mean buyers item not } \\
\text { clear some time or what } \\
\text { they want precisely) }\end{array}$ & $\begin{array}{l}\text { Electronic marketplaces } \\
\text { (many-to-many e- } \\
\text { procurement) } \\
\text { Supplier catalogue sites (sell- } \\
\text { side e-procurement) } \\
\text { Buying/ RTP applications } \\
\text { (buy-side e-procurement) } \\
\text { Major obstacles in procuring } \\
\text { goods and services through } \\
\text { an E-Procurement system } \\
\text { process }\end{array}$ & $\begin{array}{l}\text { System downtime, } \\
\text { Suppliers upload } \\
\text { information } \\
\text { Again information } \\
\text { Arrangement is needed } \\
\text { Information has to be } \\
\text { downloaded manually }\end{array}$ \\
\hline
\end{tabular}

Figure 5.6: similar characteristics of social issues that influences major obstacles in E-procurement practices from buyers and suppliers perspectives

The interview with management of procurement department in an E-procurement buyer and service provider organization reveals that:

1. System downtime, 
After suppliers upload their information we have to arrange the information again and download them manually this is how E-procurement works.

As shown in the figure above (figure 5.6), supplier's organizations is affected by a number of their own internal environments such as major obstacles that they may have faced in procuring goods and services through their catalogue sites [(supplier catalogue sites) (sell-side E-procurement)] which in turn is affected by a number of factors. Factors such as system downtime, customer service operator or slow respond, and the specification for product not clearly noticed and comparisons are not applied (Meaning that buyers item not clear some time or what customers want precisely unclear). These are factors that supplier's organizations major obstacles that they may have faced in procuring goods and services in electronic marketplaces (many-to-many E-procurement) in relations to external environments of the firms.

\subsection{Department innovation and Position}

The question was about the needs for department innovation and the needs of this development with respect to the government positions. The answer was no from suppliers point of views. However, from buyers' point of view, it was necessary to get more training courses needed for development from the government.

\begin{tabular}{|l|l|l|}
\hline $\begin{array}{l}\text { E-procurement supplier's } \\
\text { organization }\end{array}$ & $\begin{array}{l}\text { Tools and Characteristics of } \\
\text { ANT }\end{array}$ & $\begin{array}{l}\text { Buyer and service } \\
\text { provider organization }\end{array}$ \\
\hline $\begin{array}{l}\text { Supplier catalogue sites } \\
\text { (sell-side e-procurement) }\end{array}$ & $\begin{array}{l}\text { Buying/RTP applications } \\
\text { (buy-side e-procurement) } \\
\text { No }\end{array}$ & $\begin{array}{l}\text { The needs for department } \\
\text { developmental from the } \\
\text { government } \\
\text { courses. }\end{array}$ \\
\hline $\begin{array}{l}\text { Different characteristics between social issues that influences department developmental in e- } \\
\text { procurement in the SMPPs firms from buyers and suppliers perspectives }\end{array}$ \\
\hline
\end{tabular}

Figure 5.7: similar characteristics of social issues that influences for developmental of E-procurement practices from buyers and suppliers perspectives

The figure above (Figure 5.7) shows the needs for developmental department from the government of current Eprocurement system as characteristics of ANT that has influenced issues from buyers and suppliers perspectives. In both supplier catalogue sites (sell-side E-procurement) and in buying/ RTP applications (buy-side E-procurement) there are issues that affected them in different ways. For example, Buyer and service providers' organizations indicated the needs for getting more training courses the same cannot be said for supplier's organization from buyers and suppliers perspectives.

\subsection{Importance of Transparency and E-procurement Use}

The last question was about the importance of transparencies among the E-procurement players. The interview was specifically targets at the ethical behaviour of buyers in local markets and how such behaviour could have affected the transactions processes of the level E-procurement practices among players. Especially among buyers' organizations and their E-procurement practices when dealing with the government, although the interviews were targeted at both suppliers' and buyers' organizations. There is an overwhelming support that the overwhelming commodity transaction processes and the E-procurement practices were said to be based on higher transparencies processes since it is regulated on timely basis.

E-procurement supplier's organization

None and dealing with governments

\begin{tabular}{|l|l|}
$\begin{array}{l}\text { Tools and Characteristics of } \\
\text { ANT }\end{array}$ & $\begin{array}{l}\text { Buyer and service } \\
\text { provider organization }\end{array}$ \\
\hline $\begin{array}{l}\text { Electronic marketplaces } \\
\text { (many-to-many e- } \\
\text { procurement) }\end{array}$ & Never happened \\
$\begin{array}{l}\text { Buying/ RTP applications } \\
\text { (buy-side e-procurement) }\end{array}$ & \\
Buyers' moral values, & \\
$\begin{array}{l}\text { Buyers' transparency of the } \\
\text { E-procurement process }\end{array}$ & \\
\hline nsocial issues that influences ethical behaviours in e- \\
\hline
\end{tabular}

Similar characteristics between social issues that influences ethical beha
procurement in the SMPPS firms from buyers and suppliers perspectives

Figure 5.8: similar characteristics of social issues that influences in ethic in E-procurement from buyers and suppliers perspectives. 
As the figure above shows (Figure 5.8), the characteristics of ANT that may influences suppliers' organization as well as buyers and service providers' organization are buyers' moral values and buyers' transparency of the $E$ procurement process. As shown in the figure, in electronic marketplaces (many-to-many E-procurement) of ANT, both supplier catalogue sites (sell-side E-procurement) and in buying/ RTP applications (buy-side E-procurement) could be affected due to buyers' moral values and buyers' transparency in the E-procurement system as results of Eprocurement processes. Thus, the importance of buyers' moral values and buyers' transparency of the E-procurement practices are important issues. One main concern from the SMPPs firms perspectives are the buyers' moral and buyers' transparency of the E-procurement practices.

\section{CONCLUSION.}

The results and findings of E-procurement practices and transactions processes on ANT perspectives suggests suppliers and buyers satisfaction within E-procurement performance even in the face of challenges of E-procurement systems. This manifested in the buyers' positive attitude towards the suppliers. Tools such as for example, buying/ RTP applications (buy-side E-procurement), supplier catalogue sites (sell-side E-procurement), electronic marketplaces (many-to-many E-procurement), and reverse auctions (buyer-controlled online tenders) are used to demonstrate the implication of E-procurement practices and processes. Given the E-procurement active processes, there are evidences of economic developments and brighter future of continuing E-procurement practices and transactions processes between suppliers and buyers of the organizations. Technically, suppliers and buyers firms' operations were characterized by exploration of remedial measures through technology adaptation, trial \& error caused by human resources that can be more transparent to the suppliers. This was feasible due to the advantage of faster procurement, lower cost, and payment received on time, dealing through E-procurement system with suppliers without face-to-face interaction, notwithstanding the disadvantage of item and system error that had been handled by committed staff that had been trained to handle and the high job satisfaction of personals of the SMPPs firms. This is given the implemented technology and the robustness of such technology by the SMPPs firms.

\section{REFERENCE}

[1] Akman, I., A. Yazici, et al. (2005), "E-Government: A global view and an empirical evaluation of some attributes of citizens." Government Information Quarterly, Vol: 22, pp.239-257.

[2] Avgerou. C. (2000) IT and Organizational Change: An institutionalist perspective.

[3] Bijker, W. E., and J. Law, eds. (1992). Shaping Technology/ Building Society: Studies in Sociotechnical

[4] Callon, M. (1991), "Techno-Economic Networks and Irreversibility , in J. Law (ed.), A Sociology of Monsters: Essays on Power, Technology and Domination, London: Routledge, 132-64.

[5] Callon, M., and Latour, B. (1981), Unscrewing the big Leviathan: How actors macrostructure reality and how sociologists help them to do so. In Knorr-Cetina, K. D., and Cicourel, A. V. (eds.), Advances in Social Theory and Methodology: Toward and Integration of Micro- and Macro-Sociologies, Routledge and Kegan Paul, Boston, Mass. Change. Cambridge, MA: MIT Press.

[6] Chong S. and Liu K. (2000) The Social Aspects Neglected in E-Commerce. Ubiquity 1(19).

[7] Croom, S. and A. B. Jones (2007), "Impact of e-procurement: Experiences from implementation in the UK public sector." Journal of Purchasing and Supply Management, 13, 294-303.

[8] Garicano L. and Kaplan S.N. (2000) The Effects of Business-to Business Ecommerce on Transaction Costs. National Bureau of Economics Research, Cambridge, MA.

[9] Garrido-Samaniego, M. J., A. M. Gutierrez-Arranz et al. (2010), "Assesing the impact of e-procurement on the structure of the buying centre." International Journal of Information Management,30(2), 135-143.

[10] Kirsch, S. (1995) 'The incredible shrinking world? Technology and the production of space,' Environment and Planning D: Society \& Space 13(5):529-55.

[11] Law, J. (1992), "Notes on the Theory of the Actor Network: Ordering, Strategy and Heterogeneity". Systems Practice (5:4), 379-393.

[12] Lucking-Reiley D. and Spulber D.F. (2000) Business-to-Business Electronic Commerce. Department of Economics, Vanderbilt University.

[13] Noraizah. A., Konrad. P., Nurdiana. A., Norhayati. A., Fatimah. A, (2012). Actor Network Theory as the Analysis Instrument: Exploring Negotiation between Partners in E-Procurement Network. Journal of the Association for Information Systems. (2012).

[14] Orlikowski W.J. (1993) CASE Tools as Organizational Change: Investigating Incremental and Radical Changes in Systems Development. MIS Quarterly 17(3), 309-340. Performance in the Hotel Industry." Journal of Hospitality and Tourism, 30(4), 407-426.

[15] Ronchi, S., A. Brun et al. (2010), "What is the value of an IT e-procurement system?" Journal of Purchasing and Supply management, 16, 131-140.

[16] Selcen. O., Ronan. D., Nihat. K., Enes. E., (2009). An actor-network theory (ant) approach to turkish egovernment gateway initiative. International Conference on eGovernment \& Governance (Ice-Gov), Ankara, Turkey, March 12-13, 2009.

[17] Sin, L. L. M., A. C. B. Tse et al, (2006). "The Effects of Relationship Marketing Orientation on Business

[18] Stanforth, C. (2006), Analysing eGovernment Implementation in Developing Countries Using Actor-Network Theory. iGovernment. Manchester, UK.

[19] Wen, W. and L. Wei (2007), Decision-making Analysis of E-procurement with the Rough Set Theory International conference on wireless computing and networking. Shanghai.

[20] Wigand R. (1997) Electronic Commerce: Definition, theory, and context. The Information Society 13, 1-16. 